\title{
Implementing A Balanced Scorecard In A Not-For-Profit Organization
}

\author{
Michael Martello, Jamestown Community College, USA \\ John G. Watson, St. Bonaventure University, USA \\ Michael J. Fischer, St. Bonaventure University, USA
}

\begin{abstract}
$^{1}$
This paper examines the use of the Balanced Scorecard in a not-for-profit organization (Cattaraugus County ReHabilitation Center). The ReHabilitation Center has begun using the Balanced Scorecard paradigm in its strategic planning process. In this paper an overview is presented of the basic concepts of the Balanced Scorecard including the financial perspective, customer perspective, internal process perspective, and learning and growth perspective. The history and services of the ReHabilitation Center are then summarized. The application of the Balanced Scorecard approach to the ReHabilitation Center is discussed in detail. Implications in using the Balanced Scorecard are discussed. Finally, conclusions regarding the use of the Balanced Scorecard in a not-forprofit organization are presented.
\end{abstract}

Keywords: Balanced Scorecard; Not-For-Profit; Rehabilitation Center; Financial Perspective; Customer Perspective; Internal Process Perspective; Learning And Growth Perspective

\section{INTRODUCTION}

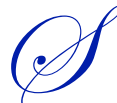

trategic Management is that set of managerial positions and actions that determines the long-run performance of an organization. It includes environmental scanning (both external and internal), strategy formulation (strategic or long-range planning), strategy implementation, and evaluation and control (Wheelan and Hunger, 2008). According to Gluck, Kaufman and Walleck (1982), managers attempt to better deal with the changing world environment by evolving through four phases of strategic management. Phase 1 involves basic financial planning. Managers initiate planning when they propose the next year's budget. Phase II involves forecast-based planning. Managers propose five-year plans when annual budgets become less useful and stimulate long-term planning. Phase III consists of externally oriented planning (strategic planning). Top management takes control of the process and initiates strategic planning due to political and ineffective five-year plans. Phase IV involves strategic management. Top management forms planning groups from managers and key employees at many levels from various departments and work groups in order to gain commitment of lower level managers. Top management realizes that for strategic plans to be effective, input and commitment from lower level managers is required.

The strategic management process has been developed and utilized successfully by many business corporations as well as governmental organizations and non-profit institutions. Nonetheless, due to the rapidity of change occurring in the environment of most organizations, the strategic management process is frequently criticized by academics as well as practitioners. There certainly are benefits to the traditional strategic management process including such things as: a clearer sense of strategic vision for the organization; sharpened focus on what is strategically important; and, improved understanding of a rapidly changing environment (Wilson, 1994). A number of challenges have surfaced in recent years, however, that have complicated the strategic management process. Some of those challenges include the impact of globalization, electronic commerce, diversification of the workforce, the learning

\footnotetext{
${ }^{1}$ This manuscript was original published in the Journal of Business \& Economics Research 6(9), 67-80. Due to high download rates this manuscript has been reprinted.
} 
organization, rapid technological advances, governmental regulations, and increasing competitive forces in the environment (Wheelan and Hunger 2008).

\section{EMERGENCE OF THE BALANCED SCORECARD}

The conceptual framework of the Balanced Scorecard was introduced by Kaplan and Norton $(1992,1993,1996)$ for the purpose of designating, evaluating and measuring factors that drive an organization's performance.

Historically, organizations placed a great deal of emphasis on financial measures in operating their organizations. According to Kaplan and Norton (1992) reliance on financial measures in a management system is insufficient, as financial measures are lag indicators that reflect the outcomes from past actions. The Balanced Scorecard paradigm retains measures of financial performance and supplements these measures with factors that drive future financial performance. The Balanced Scorecard is based upon the cause-and-effect relationships of the financial and nonfinancial measures derived from the organization's strategy. The perspective Kaplan and Norton stress moves from an emphasis on tangible assets to, and including, an emphasis on intangible assets. They asserted that intangible assets became the major source of competitive management by the end of the twentieth century. Consequently, it became necessary to develop strategies for managing an organization's intangible assets. These intangible assets include such things as customer relationships, innovative products and services, high-quality responsive operating processes, skills and knowledge of the workforce, the information technology that supports the workforce, and the organizational climate that encourages innovation, problem-solving, and improvement.

Kaplan and Norton's Balanced Scorecard concept seeks to provide managers with a set of performance metrics balanced between outcome measures and measures of the drivers of future outcomes (1996 b). It provides a framework for organizing strategic objectives into four perspectives. In each of the four perspectives, quantitative measures are developed in order to operationalize the model. The four perspectives are as follows:

- $\quad$ Financial - the strategy for growth, comparability, and risk viewed from the perspective of the shareholder.

- Customer - the strategy for creating value and differentiation from the perspective of the customer.

- Internal Business Processes - the strategic priorities for various business processes that create customer and shareholder satisfaction.

- Learning and Growth - the priorities to create a climate that supports organizational change, innovation, and growth.

\section{Financial Perspective}

Profit-seeking organizations attempt to increase shareholder value. This is typically done through two approaches increasing revenue and improving productivity. The basic intent is to improve the bottom-line. In a not-for-profit organization the emphasis is significantly different from that of a for-profit organization. The financial perspective might include a maximization of funding from outside sources instead of profit, or maintenance of fiscal stability. Certainly other factors could also be considered.

\section{Customer Perspective}

Kaplan and Norton indicate the core of any business strategy is the customer-value proposition which describes the unique mix of product, price, service, relationship, and image that a company offers. Accordingly, an organization must identify the customers it wishes to attract and the market segment in which it will compete. An organization differentiates its customer-value proposition. It selects from among operational excellence, customer intimacy, and product leadership. The customer perspective also identifies the intended outcomes from delivering a differentiated value proposition (Kaplan and Norton 2001). 
Exhibit 1. Translating Vision and Strategy: Four Perspectives

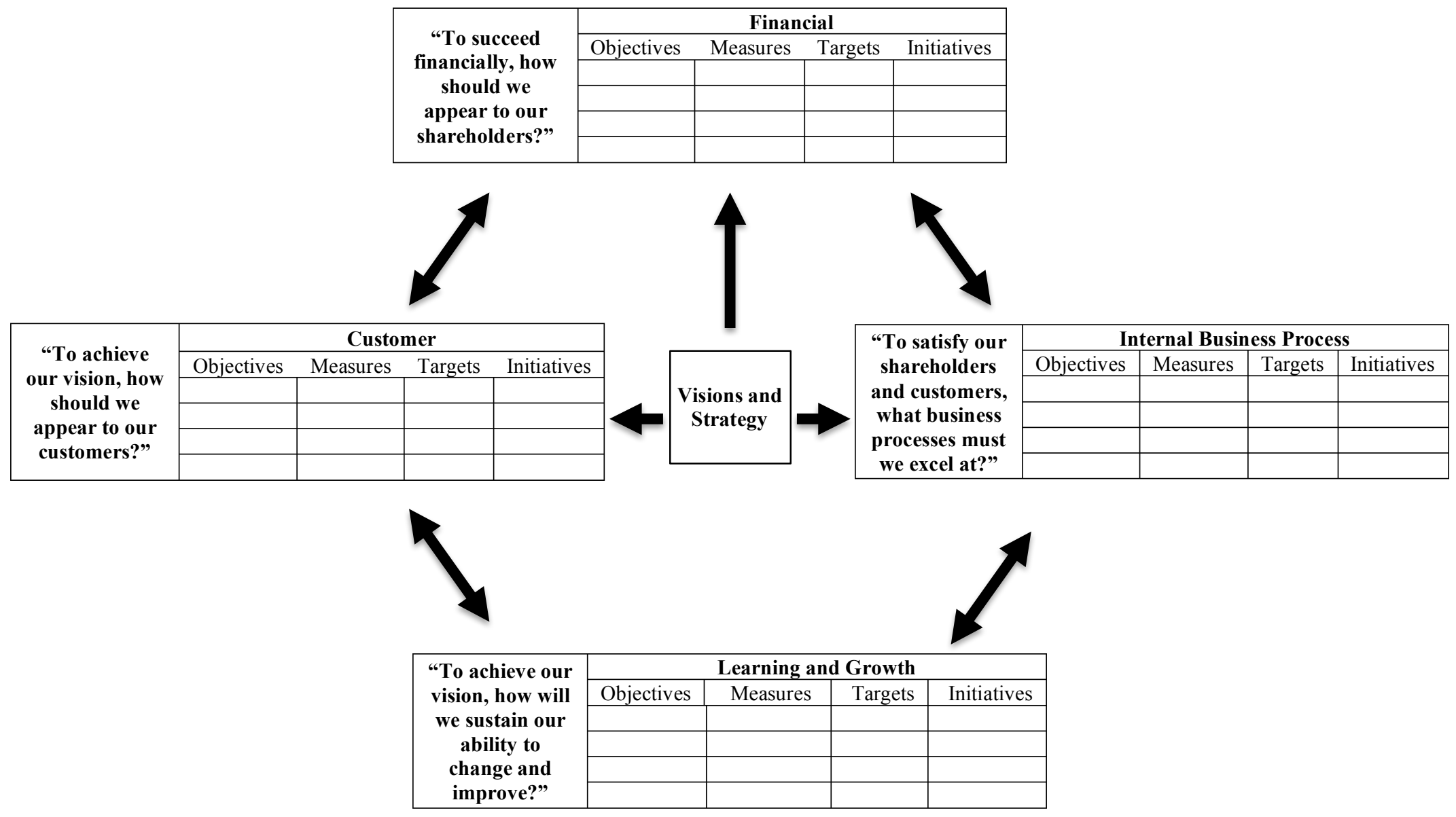




\section{Internal Process Perspective}

The internal process perspective involves the determination of the internal processes that will best affect the customers as well as the process improvements that will affect the financial objectives. In improving internal processes, there should be a connection between the overall strategy and the improvements. There should also be a determination of how the strategy is to be measured. According to Kaplan and Norton, in utilizing this approach the organization can frequently identify processes at which the organization must excel to meet its goals (Kaplan and Norton, 1996b, 2001).

\section{Learning and Growth Perspective}

The fourth category of the balanced scorecard is the learning and growth perspective, which has been identified as the foundation of any strategy. The learning and growth perspective involves a determination of employee capabilities and skills, technology, and a corporate climate needed to support a strategy. The human resources, technology and organizational climate must be aligned with the strategies within the other three perspectives giving the organization linkages among the four perspectives (Kaplan and Norton, 1996 b, 2001).

Exhibit 1 shows how the Balanced Scorecard defines a strategy's cause-and-effect relationships through the four perspectives.

\section{USE OF THE BALANCED SCORECARD}

Since the introduction of the Balanced Scorecard approach by Kaplan and Norton, the methodology has been utilized in a number of for-profit and not-for-profit organizations. The literature is replete with examples of the successful implementation of the Balanced Scorecard approach, especially in for-profit organizations.

In the for-profit sector, companies have recognized that financial metrics by themselves are inadequate for measuring and managing their performances (Kaplan 2001). Kaplan and Norton (1992, 1996) complemented the financial perspective with the other three perspectives: the customer, the internal process, and learning and growth. For-profit seeking corporations, the financial perspective provides clear long-run objectives (Kaplan 2001).

On the other hand, in the not-for-profit sector, the financial perspective provides a constraint rather than an objective. While the not-for-profits monitor spending and adhere to financial budgets, their success or failure is not measured by spending in relationship to budgeted amounts. According to Kaplan, the typical not-for-profit has had difficulty placing the financial perspective at the top of the Balanced Scorecard. He suggests that the not-for-profits consider placing a mission objective at the top of their scorecard as the mission represents the accountability between the not-for-profit and society. He also suggests the not-for-profits expand the definition of who their customer is. As noted by Kaplan, a growing number of not-for-profits have begun using the Balanced Scorecard model (Kaplan 2001).

\section{AN OVERVIEW OF THE REHABILITATION CENTER}

The ReHabilitation Center was created more than five decades ago by a group of parents who had children with disabilities. An advertisement was placed in a local newspaper by one of the parents, and on October 2, 1957, a small group of parents who had children with disabilities met to share with one another their individual frustrations. The group immediately began advocating for children with disabilities. In 1958 the organization became incorporated. Today, the ReHabilitation Center is a multi-faceted agency that serves hundreds of individuals at more than thirty-five sites throughout Cattaraugus County and surrounding counties in New York State. The ReHabilitation Center is dedicated to improving the quality of life of people with disabilities. It provides comprehensive services to assist each individual in achieving maximum independence. This mission is pursued by all the ReHabilitation Center personnel within a values-based culture. A significant number of services are provided by the ReHabilitation Center, which include the following.

Children's Learning Center (CLC) 
The CLC serves infants, toddlers and preschoolers through early childhood screenings, special education and therapy in integrated settings. At CLC, it is the belief that the earlier a child with a disability receives assistance, the better prepared that child will be to face the challenges of the future.

\section{Residential Services (RS)}

RS provides a continuum of community living options to adults and children with developmental disabilities. RS is dedicated to providing safe, comfortable homes with varying levels of supervision. In addition, the RS program instructs residents in community living skills while promoting choice, dignity and independence.

\section{SubCon Industries}

SubCon Industries provides employment training opportunities for adults with disabilities. It is dedicated to developing vocational skills and good work habits in the people it serves as a way of increasing their self-esteem and helping them become productive and contributing members of the community. Without SubCon, many of its workers would languish in their homes without achieving the personal growth and sense of self-worth they develop through their work at SubCon.

\section{Sports \& Recreation}

The division of Sports \& Recreation provides year-round sports training and competition, as well as leisure and educational opportunities for adults with disabilities. This program offers vacations including same-day shopping trips, Saturday respite, overnight stays in Buffalo, weekend getaways, and three- to five- day vacations. The ultimate goal of this program is to enhance the participants' quality of life by offering the benefits of health and wellness, teamwork, sports skills, self-confidence and personal achievement.

\section{The Employment Connection}

The Employment Connection provides a wealth of vocational services to people with disabilities or disadvantages. In addition to securing community-based employment training and placement for individuals, The Employment Connection is dedicated to helping people maintain their employment through a combination of case management and job coaching.

\section{Lifeskills}

Lifeskills is a division that provides day programming to adults with developmental disabilities. In addition to instruction in daily living skills, Lifeskills offers participants opportunities for community integration with a goal of increasing independence.

\section{Medicaid Service Coordination}

Medicaid Service Coordination is a division that coordinates Medicaid Waiver Services by providing case management, linkage to services and funds for environmental modifications and adaptive technology, and referrals to other community resources.

\section{Continuing Day Treatment}

Continuing Day Treatment is a division that provides weekday services for adults who are dually diagnosed with a mental health disorder and a developmental disability. Dedicated to meeting the complex needs of an under-served population, Continuing Day Treatment is a model program that has generated interest from other human service providers throughout the country. 


\section{The ReHabilitation Center Clinic}

The ReHabilitation Center Clinic is a certified health facility providing individuals with developmental disabilities convenient access to a variety of clinical services. These are provided through a cooperative arrangement with the Western New York Developmental Disabilities Service Office. The goal of The ReHabilitation Center Clinic is to assist children and adults with developmental disabilities to improve, enhance and maintain the quality of their lives. This is accomplished by providing resources to the individual, families, care givers and any significant others who affect or are affected by involvement with persons served by the Clinic. Services focus on enabling individuals to make successful adaptations to attain realization of the life goals through a variety of evaluations, comprehensive treatment planning, and technical assistance.

\section{Applied Behavior Analysis (ABA)}

The ABA program was recently implemented for the purpose of treating children with autism. Autism is a complex developmental disability that typically appears during the first three years of life. Autism impacts the normal development of the brain in the areas of social interaction and communication skills. Children and adults with autism typically have difficulties in verbal and non-verbal communications, social interactions, and leisure or play activities.

\section{Volunteer Opportunities}

The Side-By-Side volunteer program is composed of individuals willing to donate their time and talents to help improve the quality of life of people with disabilities. A wide variety of volunteer experiences are available in many different areas of The ReHabilitation Center: Residential Services, Sports \& Recreation Program, Arts \& Crafts, Mentor Program, Big brother/Big sister program, Fund-Raising events, Manufacturing/Production, Guardianship, Medicaid Service Coordination and Clerical Support.

As is quite obvious from the above, the ReHabilitation Center provides a myriad of activities and services for individuals with disabilities in an attempt to integrate these individuals into the community.

\section{APPLICATION OF THE BALANCED SCORECARD TO THE REHABILITATION CENTER}

The ReHabilitation Center has been involved in the process of strategic planning for a number of years. Over the years, consultants have been utilized by the Center to assist in the strategic planning process. However, while the top management group at the Center has participated in developing strategic plans based upon the input from the consultants, they found it very difficult to bridge the gap between strategic planning and the day-to-day activities within the Center. The management group was never able to develop a strategic plan that they considered to be a "living, breathing document". Any strategic plan that was developed did not pervade the entire organization. It was not "pushed down" to the lower levels within the organization and was not aligned with the day-to-day activities of the Center.

Approximately nine years ago, the Center appointed a Director of Strategic Planning. After thoroughly exploring the strategic planning process, the new director decided to utilize the concept of the Balanced Scorecard as a tool to cascade strategic planning throughout the entire organization. The ultimate goal was to have each area within the Center aligning itself with the overall strategic plan. Each area would then develop outcome measures that were aligned with the overall strategic objectives of the Center. While a number of measurements or metrics are readily available or easily discernible in for-profit organizations, the number of measurements or metrics are not so readily available in the not-for-profit sector-especially for a ReHabilitation Center where the population of consumers have developmental disabilities.

To effectively implement the Balanced Scorecard approach within the Center, the participation and acceptance of the system by all personnel was essential. At the outset many individuals were unsure of the Balanced Scorecard approach and saw it as another "flavor of the month" strategic planning approach that once again "would take time away from completing their day-to-day activities". After a period of time the director was able to convince the top 
level managers that the Balanced Scorecard approach would lead to more effective strategic planning for the Center. The early views of the top level managers were slowly eradicated as they began working with the director in developing specific outcomes or results expected of them in their individual areas of responsibility. The director was able to obtain support from the top level managers as they accepted the concept and were willing to give it a try. The real challenge was to obtain the "buy in" from all managers in the Center so they would "own the Balanced Scorecard concept".

Since the consumers of the ReHabilitation Center are individuals with developmental disabilities, it was extremely difficult to develop outcome measures for a number of areas within the Center. Nonetheless, the Balanced Scorecard system was introduced into the Center. As a result of the efforts of personnel within the entire organization, the Center developed a strategic plan for the years 2002-2005. This strategic plan has been updated on a yearly basis.

Exhibit 2 presents the corporate Mission, Vision and Values of the Center. In reviewing the Mission statement in Exhibit 2, it is quite obvious the major emphasis of the Center is with the consumer. The consumer consists of individuals with disabilities, and the intent of the Mission is to provide comprehensive services for those individuals so they might achieve maximum independence.

The Vision of the Center is to be "a leader in providing and assessing desired services to people with disabilities". Both the Mission and Vision are to be attained through individuals in the organization working in an environment that espouses a Values-based culture. According to the President and CEO of the Center, it is the Values that reflect "who we are, what we do, who we serve and the Values that hold it all together - Values without which we simply would not be the vibrant, living organization we are". The Values delineated by the Center include: integrity, positivity, learning, loyalty, respect, and results oriented.

Exhibit 2. Mission - Vision - Values

\begin{tabular}{l} 
Mission \\
\hline The ReHabilitation Center is dedicated to improving the quality of life of people with disabilities by providing and/or accessing \\
comprehensive services to assist each individual in achieving maximum independence. We will pursue this mission within our \\
values-based culture.
\end{tabular}

\section{Vision}

To be a leader in providing and accessing desired services to people with disabilities. Emphasis will be placed on: need, choice, independence, natural environment, quality of life, and becoming valued contributors in their communities.

\begin{tabular}{ccc}
\hline & Values & Loyalty \\
\hline Integrity & Respect \\
Positivity & Results Oriented \\
Learning & & \\
\hline
\end{tabular}


Exhibit 3. The Rehabilitation Center Balanced Scoreboard Strategy Map

The Rehab Center is dedicated to improving the quality of life of people with disabilities by providing and/or accessing comprehensive services to assist each individual in achieving maximum independence. We will

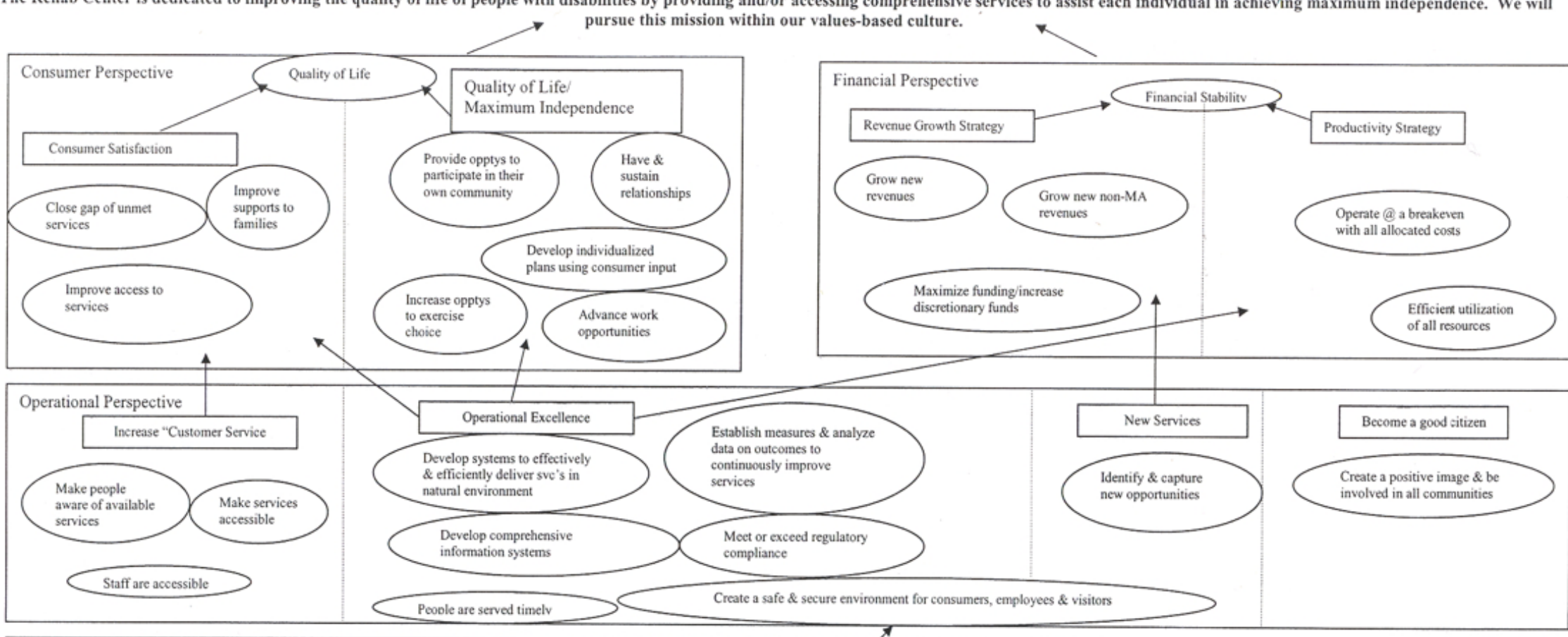

Learning Perspective
Develop recognition
programs for employees


Exhibit 3 is a strategy map that presents the strategic objectives in the four perspectives for the Center. In looking at the strategy map, it is of paramount importance to note the consumer perspective and the financial perspective are placed together at the top of the map. While private-sector organizations typically emphasize the financial aspects for an organization, not-for-profit organizations more frequently place greater emphasis on the customer. The Center considers the consumer perspective and the financial perspective to be equal in importance. While this emphasis differs from the suggested format of Kaplan, it, nonetheless, provides a framework that is very suitable for the Center. There is no question as to the importance of the consumer for the Center. However, due to the limited financial resources available to the Center, it has become necessary for the Center to constantly look for funding. There are a number of other agencies and organizations vying for funding, and as a consequence of this, the Center is constantly looking for additional financial resources. In addition, the Center has attempted to look at its internal processes to gain efficiencies without cutting expenses. It is for these reasons the Center places equal importance on the customer and financial perspectives.

\section{THE FOUR PERSPECTIVES}

Concerning the consumer perspective, the intent is to improve the quality of life in two respects. First, the Center strives to provide consumer satisfaction by closing the gap of unmet services; improving access to services by the consumers; by attempting to improve support to the families of the individuals with disabilities; and, by increasing services in the natural environments. Second, the Center strives to improve the quality of life of the consumer by giving them maximum independence. This is accomplished by providing opportunities for them to participate in their own community; assisting them in developing and sustaining relationships; developing individualized plans using the input from the consumer; increasing opportunities for them to exercise choices; and, providing them with work opportunities.

Concerning financial stability, the Center attempts to increase revenues as well as improve productivity within the Center. In expanding revenues the Center has attempted to obtain new revenue sources; obtain new non-MA revenues; maximize prior funding; and, increase discretionary funds. The Center also has attempted to operate at a breakeven level with all available funding and provide for efficient utilization of all resources.

In support of achieving their consumer and financial goals, the Center has developed numerous goals within the operational perspective. For example, in support of their consumer services goals, the Center has attempted to deepen and improve its relationship with consumers and their families by making the public aware of available services; by making services accessible to individuals with developmental disabilities; and, making certain the staff within the Center is accessible. Further, the Center knows that to reach its consumer goals as well as to improve productivity, it must excel in its operational processes. Specifically, the Center has attempted to provide operational excellence by developing systems to effectively and efficiently deliver services in the natural environment; by developing a comprehensive information system; by insuring that people are served in a timely fashion; by establishing measures and analyzing data on outcomes to continually improve services; by meeting and exceeding regulatory requirements; and, by creating a safe and secure environment for consumers, employees and visitors. The Center also has attempted to identify and implement new service opportunities for individuals with disabilities in an effort to grow its revenue base. Last, by creating a positive image and being actively involved in the community, the Center knows it will create long-term benefits necessary to achieve its goals.

Just as it is necessary to have operational goals to support its consumer and financial objectives, the Center realizes it must have a workforce, technology and an environment conducive to achieving its operational goals. With $75 \%$ of its operating budget dedicated to employee wages and benefits, the Center understands the importance of developing a motivated, prepared and satisfied workforce. In order to satisfy this strategic objective the Center has attempted to increase staff competencies; to develop programs to recognize the efforts of employees; to provide personal growth opportunities within the Center for employees; and, to recruit, orient, manage, develop and retain employees. The Center knows that to accomplish many of its goals, it must also improve its use of technology within the Center by employing technology to support onsite services and by using technology to develop information systems. Finally, the Center believes that a strong culture is essential to giving guidance to its employees and creating an environment that maximizes the contributions of its employees. As such, the Center has attempted to improve its culture by improving the strategic alignment and communication throughout the Center, and by promoting and practicing corporate values. Exhibits $4 \mathrm{~A}$ through $4 \mathrm{E}$ contain the strategic objectives for each of the four perspectives for the Center. These Exhibits also contain the core indicators and measurements for each of the strategic objectives. The core indicators and measurements provide the Center with specific outcomes desirable to carry out the strategic plan. These scorecards link the overall long-range strategies to each and every area of the Center. All subunits of the organization are thus tied to the strategic plan. 


\section{Exhibit 4A}

\begin{tabular}{|c|c|c|c|}
\hline \multicolumn{4}{|c|}{$\begin{array}{c}\text { Corporate BSC } \\
6 / 08\end{array}$} \\
\hline Perspective & Strategy & Objective & Core Indicators/Measures \\
\hline \multirow[t]{26}{*}{ Consumer } & $\begin{array}{l}\text { Improve Quality of Life - } \\
\text { Maximize Independence }\end{array}$ & $\begin{array}{l}\text { Provide opptys for consumers to } \\
\text { participate in their communities }\end{array}$ & $\begin{array}{l}\% \text { of people who participate in integrated } \\
\text { community activities }\end{array}$ \\
\hline & & & \# of public educational activities \\
\hline & & & Avg \# of activities per person \\
\hline & & Have \& sustain relationships & $\begin{array}{l}\% \text { of people with friends and/or caring } \\
\text { relationships (excl staff/family) }\end{array}$ \\
\hline & & & $\begin{array}{l}\% \text { of people that see family/friends when they } \\
\text { want }\end{array}$ \\
\hline & & & $\%$ of people feeling lonely \\
\hline & & Advance work opportunities & Avg monthly wage \\
\hline & & & Avg \# of work hours \\
\hline & & & $\%$ of people earning minimum wage or better \\
\hline & & & $\begin{array}{l}\% \text { of people continuously employed in } \\
\text { community based setting }\end{array}$ \\
\hline & & & $\begin{array}{l}\% \text { of people engaged in community integrated } \\
\text { employments who receive daytime supports } \\
\text { of any type }\end{array}$ \\
\hline & & Exercise choice over their lives & $\begin{array}{l}\% \text { of people who make life choices (housing, } \\
\text { jobs, staff, routines, etc) }\end{array}$ \\
\hline & & & $\begin{array}{l}\% \text { of people that feel their service plan } \\
\text { include things that are important to them }\end{array}$ \\
\hline & & & $\%$ of people that control their own spending \\
\hline & & $\begin{array}{l}\text { With consumer input, Agency } \\
\text { plans, designs \& deliver quality } \\
\text { individualized services }\end{array}$ & $\begin{array}{l}\% \text { of people who participated in developing } \\
\text { their service plan }\end{array}$ \\
\hline & & & $\begin{array}{l}\% \text { of consumers achieving " } \mathrm{x} " \% \text { of goals: } \\
\text { total served }\end{array}$ \\
\hline & $\begin{array}{l}\text { Increase Consumer } \\
\text { Satisfaction }\end{array}$ & Close the gap of unmet services & $\begin{array}{l}\% \text { of people who report that needed services } \\
\text { were not available }\end{array}$ \\
\hline & & & \# on the waiting list \\
\hline & & Increase consumer satisfaction & $\begin{array}{l}\% \text { of people satisfied with their living } \\
\text { arrangements }\end{array}$ \\
\hline & & & $\begin{array}{l}\% \text { of people satisfied with their job \&/or day } \\
\text { program }\end{array}$ \\
\hline & & & $\%$ of people satisfied with supports \\
\hline & & & COQ survey \\
\hline & & $\begin{array}{l}\text { Increase services in natural } \\
\text { environment }\end{array}$ & $\begin{array}{l}\text { \# of consumers served in natural } \\
\text { environments }\end{array}$ \\
\hline & & $\begin{array}{l}\text { Improve access to } \\
\text { needed/wanted services }\end{array}$ & $\begin{array}{l}\% \text { of people who can receive or be linked to } \\
\text { the services they want }\end{array}$ \\
\hline & & & $\begin{array}{l}\text { \# of DBL persons served: \# of DBL persons } \\
\text { in Catt Co. }\end{array}$ \\
\hline & & Improve supports to families & $\begin{array}{l}\% \text { of satisfaction by families of residential } \\
\text { person with supports received }\end{array}$ \\
\hline
\end{tabular}


Exhibit 4B

Corporate BSC

$6 / 08$

\begin{tabular}{|c|c|c|c|}
\hline Perspective & Strategy & Objective & Core Indicators/Measures \\
\hline & & & $\begin{array}{l}\% \text { of satisfaction by families of person not } \\
\text { living in home with supports \& involvement }\end{array}$ \\
\hline \multirow[t]{15}{*}{ Financial } & Maintain financial stability & Maintain financial stability & Ratio of current assets to current liabilities \\
\hline & & & Ratio of total assets to total liabilities \\
\hline & & & Cash flow \\
\hline & & & $\%$ of private revenues to total revenues \\
\hline & & & Balanced Budget/Net Income \\
\hline & Grow New Revenues & Grow new service revenues & Gross Revenues (net trends) \\
\hline & & Grow new non-medicaid revenues & $\%$ of non-MA revenues: total revenues \\
\hline & & $\begin{array}{l}\text { Maximize funding/increase } \\
\text { discretionary funds within } \\
\text { corporate configuration }\end{array}$ & Gross Revenues (net trends) \\
\hline & & & Net revenues \\
\hline & $\begin{array}{l}\text { Improve } \\
\text { Productivity/efficiency }\end{array}$ & $\begin{array}{l}\text { Operate at a breakeven or better } \\
\text { including all allocated costs }\end{array}$ & Net income \\
\hline & & Efficient utilization of resources & $\begin{array}{l}\text { Avg cost per person by living arrangement, } \\
\text { type of service }\end{array}$ \\
\hline & & & $\begin{array}{l}\% \text { of expenditure by living arrangement, } \\
\text { type of svc to total expenditures }\end{array}$ \\
\hline & & & $\begin{array}{l}\text { Avg time from intake to eligibility to } \\
\text { service }\end{array}$ \\
\hline & & & Cost/unit \\
\hline & & & Efficiency Ratio \\
\hline
\end{tabular}

Exhibit 4C

\section{Corporate BSC}

$6 / 08$

\begin{tabular}{|c|c|c|c|}
\hline Perspective & Strategy & Objective & Core Indicators/Measures \\
\hline \multirow[t]{14}{*}{ Operational } & $\begin{array}{l}\text { Identify \& capture new service } \\
\text { opportunities }\end{array}$ & $\begin{array}{l}\text { Identify \& capture new service } \\
\text { opportunities }\end{array}$ & \# of new opportunities identified \\
\hline & $\begin{array}{l}\text { Achieve Operational } \\
\text { Excellence }\end{array}$ & $\begin{array}{l}\text { Create a safe \& secure } \\
\text { environment for consumers, } \\
\text { employees \& visitors }\end{array}$ & \# of reportable injuries \\
\hline & & & \# of medication errors reported \\
\hline & & & $\begin{array}{l}\% \text { of people that receive physical exams } \\
\text { in past year }\end{array}$ \\
\hline & & & $\%$ of people that feel safe in their homes \\
\hline & & & \# of workplace accidents/incidents \\
\hline & & & \# of reportable incidents \\
\hline & & $\begin{array}{l}\text { Develop systems to effectively \& } \\
\text { efficiently deliver services in } \\
\text { natural environment }\end{array}$ & Cycle time from intake to admission \\
\hline & & $\begin{array}{l}\text { People are served in a timely } \\
\text { fashion }\end{array}$ & $\begin{array}{l}\text { Avg time from intake to eligibility to } \\
\text { service }\end{array}$ \\
\hline & & & Avg days on waiting list \\
\hline & & & Cycle time from intake to admission \\
\hline & & $\begin{array}{l}\text { Develop comprehensive } \\
\text { information systems }\end{array}$ & $\begin{array}{l}\text { \# of reports produced from automated } \\
\text { data }\end{array}$ \\
\hline & & $\begin{array}{l}\text { Establish measures \& analyze } \\
\text { data on outcomes to continuously } \\
\text { improve services }\end{array}$ & $\#$ of trend reports related to goals \\
\hline & & $\begin{array}{l}\text { Meet or exceed regulatory } \\
\text { compliance }\end{array}$ & \# of citations from survey \\
\hline
\end{tabular}


Exhibit 4D

Corporate BSC

$6 / 08$

\begin{tabular}{|c|c|c|c|}
\hline Perspective & Strategy & Objective & Core Indicators/Measures \\
\hline & $\begin{array}{l}\text { Increase consumer } \\
\text { relationship/"customer } \\
\text { service" }\end{array}$ & $\begin{array}{l}\text { Make people aware of available } \\
\text { resources/services }\end{array}$ & $\%$ of people satisfied with services \\
\hline & & $\begin{array}{l}\text { People have access to services \& } \\
\text { supports }\end{array}$ & $\begin{array}{l}\% \text { of people who have adequate } \\
\text { transportation }\end{array}$ \\
\hline & & & $\begin{array}{l}\text { \# of people, age-adjusted \& risk-adjusted } \\
\text { receiving services, by age, service } \& \\
\text { living arrangement }\end{array}$ \\
\hline & & $\begin{array}{l}\text { Appropriate staff are accessible, } \\
\text { responsive \& supportive }\end{array}$ & $\begin{array}{l}\% \text { of people satisfied with } \\
\text { "customer service" }\end{array}$ \\
\hline & & & $\begin{array}{l}\% \text { of people who are able to access } \\
\text { appropriate staff in a timely fashion }\end{array}$ \\
\hline & $\begin{array}{l}\text { Develop effective } \\
\text { relationships with external } \\
\text { communities (good citizen) }\end{array}$ & $\begin{array}{l}\text { Create a positive image } \& \text { be } \\
\text { involved in all communities }\end{array}$ & Public survey \\
\hline & & & $\begin{array}{l}\text { \# of partnerships with community } \\
\text { agencies }\end{array}$ \\
\hline
\end{tabular}

EXHIBIT 4E

Corporate BSC

$6 / 08$

\begin{tabular}{|c|c|c|c|}
\hline Perspective & Strategy & $\begin{array}{c}\text { Objective } \\
\end{array}$ & Core Indicators/Measures \\
\hline \multirow[t]{14}{*}{ Learning } & $\begin{array}{l}\text { Create a motivated, prepared } \\
\& \text { satisfied workforce }\end{array}$ & $\begin{array}{l}\text { Recruit, orient, manage, develop \& } \\
\text { retain personnel }\end{array}$ & turnover rate \\
\hline & & & \# of days position vacant \\
\hline & & & avg length of employment \\
\hline & & & $\%$ of direct care overtime hrs \\
\hline & & $\begin{array}{l}\text { Develop recognition programs for } \\
\text { employees }\end{array}$ & \# of employee recognition programs \\
\hline & & Increase staff competencies & $\begin{array}{l}\% \text { of staff successfully completing } \\
\text { training }\end{array}$ \\
\hline & & & $\begin{array}{l}\% \text { of staff meeting minimum } \\
\text { competency requirements }\end{array}$ \\
\hline & & $\begin{array}{l}\text { Provide personal growth } \\
\text { opportunities to employees }\end{array}$ & $\#$ of personal growth programs offered \\
\hline & & Increase employee satisfaction & Employee satisfaction survey \\
\hline & Utilize Technology & $\begin{array}{l}\text { Employ technology to support } \\
\text { offside services provision }\end{array}$ & $\begin{array}{l}\# \text { of staff able to utilize offsite electronic } \\
\text { communication }\end{array}$ \\
\hline & & $\begin{array}{l}\text { Employ technology to develop } \\
\text { information systems }\end{array}$ & $\%$ of data captured once \\
\hline & $\begin{array}{l}\text { Improve Organizational } \\
\text { Culture }\end{array}$ & $\begin{array}{l}\text { Improve strategic alignment \& } \\
\text { communication throughout the } \\
\text { agency }\end{array}$ & $\begin{array}{l}\% \text { of depts. with strategic plans } \\
\text { supporting goals }\end{array}$ \\
\hline & & & \# of job descriptions with strategic goals \\
\hline & & $\begin{array}{l}\text { Promote, train } \& \text { practice corporate } \\
\text { values }\end{array}$ & \# of value based training hrs \\
\hline
\end{tabular}

\section{IMPLICATIONS IN USING THE BALANCED SCORECARD}

The Center has experienced a number of benefits with the implementation of the Balanced Scorecard. Perhaps the greatest benefit is the realization by personnel within the Center that strategic planning is a significantly more encompassing process than merely looking at long-range planning. With the utilization of the Balanced Scorecard 
paradigm, individuals throughout the Center have become involved in focusing on the linkages between each segment of the Center and the strategic plan. It is necessary to align each area of the Center with the overall strategic objectives.

Another significant benefit concerns the focus on measurements or metrics within the Center. It is extremely difficult and time consuming to develop metrics in not-for-profit organizations. However, with considerable effort, the Center has begun to develop metrics that do provide linkages to the overall strategic plan.

The Center has also begun to focus on the importance of stressing the interrelationship among the four perspectives in the Balanced Scorecard model. This has enabled the individuals working in the Center to stress things they had not previously even thought about.

According to individuals working at the Center, the benefits significantly outweigh the time requirements in utilizing the Balanced Scorecard.

\section{CONCLUSIONS}

The conceptual framework of the Balanced Scorecard has been implemented and utilized effectively for years in a large number of for-profit organizations. More recently, the model has been effectively utilized in not-for-profit organizations as well.

In this paper the authors have described how the Balanced Scorecard approach has been implemented in a ReHabilitation Center. In implementing the Balanced Scorecard approach, the ReHabilitation Center has placed equal emphasis on the consumer perspective and the financial perspective. This equal focus is based upon the necessity of the Center to carry out its primary mission for its consumers (individuals with developmental disabilities) as well as the necessity to maintain financial stability within the Center. The emphasis on both of these perspectives has become a necessity in order for the Center to efficiently and effectively serve its customers.

While the use of the Balanced Scorecard in the long range planning process for the Center is relatively new, the process has been accepted by the management of the organization. The challenge ahead for the Center is to continue to develop outcome measures for the individual departments within the Center and tie these outcome measures to the strategic objectives of the Center. It is recognized this is an extremely difficult process as real outcomes are not easily measurable. The formulation of outcome measures is a continuous development process. It is felt this process will definitely enhance the efficiency and effectiveness of the ReHabilitation Center in the long run.

\section{AUTHOR INFORMATION}

Michael Martello Vice President for Administration, Jamestown Community College, USA.

John G. Watson Professor Emeritus of Management (deceased), St. Bonaventure University, USA.

Michael J. Fischer Professor of Accounting, St. Bonaventure University, USA.

\section{REFERENCES}

Gluck, F.W., Kaufman, S.P., and Walleck, A.S. “The Four Phases of Strategic Management,” Journal of Business Strategy (Winter 1982), pp. $417-456$.

Kaplan, R. and Norton, D. 1992. “The Balanced Scorecard - Measures That Drive Performance.” Harvard Business Review 70(1): 71-79.

Kaplan, R. and Norton, D. "Putting the balanced scorecard to work." Harvard Business Review 199371 (5): 134 - 147.

Kaplan, R. and Norton, D. "Using the balanced scorecard as a strategic management system." Harvard Business Review 1996a 74 (1): $75-85$.

Kaplan, R. and Norton, D. The Balanced Scorecard. Boston, MA: Harvard Business School Press 1996b.

Kaplan, R. and Norton, D. "Transforming the Balanced Scorecard From Performance Measurement to Strategic Management: Part I." Accounting Horizons Vol. 15 No. 1 (March 2001), pp. 87 - 104. 
Kaplan, R. "Strategic Performance Measurement and Management in Nonprofit Organizations," Nonprofit Management and Leadership (Spring 2001), pp. 353 - 370.

Wheelen, T. L. and Hunger, J.D. Concepts in Strategic Management and Business Policy. New Jersey: Prentice Hall, 2008.

Wilson, I., “Strategic Planning Isn’t Dead - It Changed,” Long Range Planning (August 1994), p. 20. 